\title{
Study of Education and Development of Baiga Tribe in District Mandla
}

\author{
Ekta Mathniyan* \\ Research Scholar, Department of Geography, RDVV, Jabalpur, 482001 (M.P.), India \\ *Corresponding Author: Ekta Mathniyan, Research Scholar, Department of Geography, RDVV, \\ Jabalpur, 482001 (M.P.), India
}

\begin{abstract}
Education plays an important role in socio-economical phase. To include Baiga tribe in main stream of development, education can be an important aid. After independence, efforts are being made to improve their development and their education in India. Literacy is one of the important things which can help them to stand them at similar level to others. This research is to understand the various development levels by Government for Baiga tribe. And understand scope of improvements.
\end{abstract}

\section{INTRODUCTION}

Literacy is the key which contribute to earn livelihood, help to increase their resources as well as help to build developed country. Additionally it helps to build their own thoughts.

Situation of Baiga regions are not good while comparing other regions, because even today majority of Baiga tribes resident are situated in Jungles and far from other developed areas. These areas are lack in, like electricity education, roads, hospitals, etc, basic needs. While comparing to other areas, people in these areas are very poor because of no employment, lack of educations, and lack of basic needs.

There are 425 schedule casts, out of which 43 schedule casts are present in Madhya Pradesh. Out of these 43 casts, three are Baiga, Bharia and Sahria are declared as special cast, which is called as "Adim Janjati". As per census 2011 total population of Baiga is 4,14,526 in Madhya Pradesh.

\subsection{An Introduction to Baiga Tribe}

Baiga tribe mostly present in Dindori, Mandla, Sahdol, Anupur and Balaghat. The subtypes of Baiga are Bijhvaar, Bhumia, Bharotia, Nahar, Bhana, Muria, Kodvan, Gond, etc.

\section{STUdy AREA}

Research is conducted in Madla district (M.P.), India. Geographically Mandla is situated $23^{\circ} 12$ $\mathrm{N} 81^{\circ} 51 \mathrm{E}$. Its total area is 8771 square kilometer.

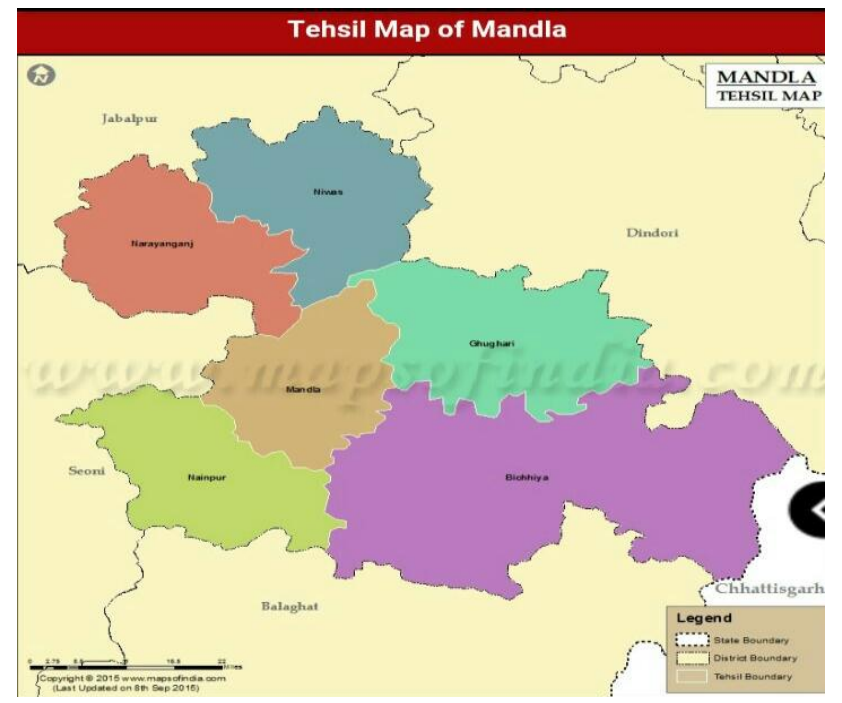


Altitude of Jabalpur is approx. 877 meter above the sea level. Its summer temperature is $46^{\circ} \mathrm{C}$ (maximum) and $19^{\circ} \mathrm{C}$ (minimum) while it varies from $27^{\circ} \mathrm{C}$ to $8^{\circ} \mathrm{C}$ in winter.

As per census 2011, Madla district has a population of 1053522 .

Madla has 4 Tahsil (Nainpur, Mandla, Bichiya, Niwas) and 9 blocks (Nainpur, Madla, Mohgaon, Ghugri, Mawai, Bichiya, Bijadandi, Narayanganj, Niwas.

Majorly Gond, Baiga and Kole tribe are lived in Mandla district. Out of total population, population of Biaga tribe is 43331 .

\section{OBJECTIVE OF STUDY}

To understand the education progress of Baiga.

To study their Social and economic condition.

Analysis of increase or decrease of literacy level of Baiga.

\section{ReSearch Methodology and Data Collection}

To study this research, data have been collected based on primary and secondary data collection method. Primary data collection has been done based on interview and secondary data is collected from district Gazetteer.

\section{EDUCATION AND DEVELOPMENT}

Due to poverty level, big family, lack of facilities in schools, marriage under age, lack of Teachers, lack of transportation, etc. Many educational schemes have been introduced by Government to increase level of education and development for Baiga Tribes and other similar tribes, to include them and make them the advantages of education.

We can also refer below table where we can see that Government is committed and trying to increase education and development level in each stage. However, there is big scope of improvement. But awareness and level at each stage is increasing step by step, which can first stone every time in improvement of Baiga's development.

Below is the table which can help us to understand education facilities and how these are subdivided demographically.

\begin{tabular}{|l|l|l|l|l|l|l|}
\hline \multicolumn{1}{|c|}{ Education Level } & Male & Percentage & Female & Percentage & Total & Percentage \\
\hline Literacy level without School & 1073 & $8-41$ & 674 & $5-10$ & 1747 & $6-72$ \\
\hline Primary School & 3182 & $25-72$ & 2581 & $19-53$ & 5863 & $22-57$ \\
\hline Middle School & 1363 & $10-68$ & 748 & $5-66$ & 2111 & $8-13$ \\
\hline High School & 104 & $3-14$ & 92 & $0-70$ & 493 & $1-90$ \\
\hline Inter College & 124 & $0-97$ & 78 & $0-14$ & 142 & $0-55$ \\
\hline Colleges & 41 & $0-32$ & 10 & $0-08$ & 51 & $0-20$ \\
\hline Others & 476 & $3-73$ & 544 & $4-12$ & 1020 & $3-93$ \\
\hline Illiterates & 6001 & $47-02$ & 8551 & $64-69$ & 14552 & $56-01$ \\
\hline Total & 12762 & & 13218 & & 25980 & \\
\hline
\end{tabular}

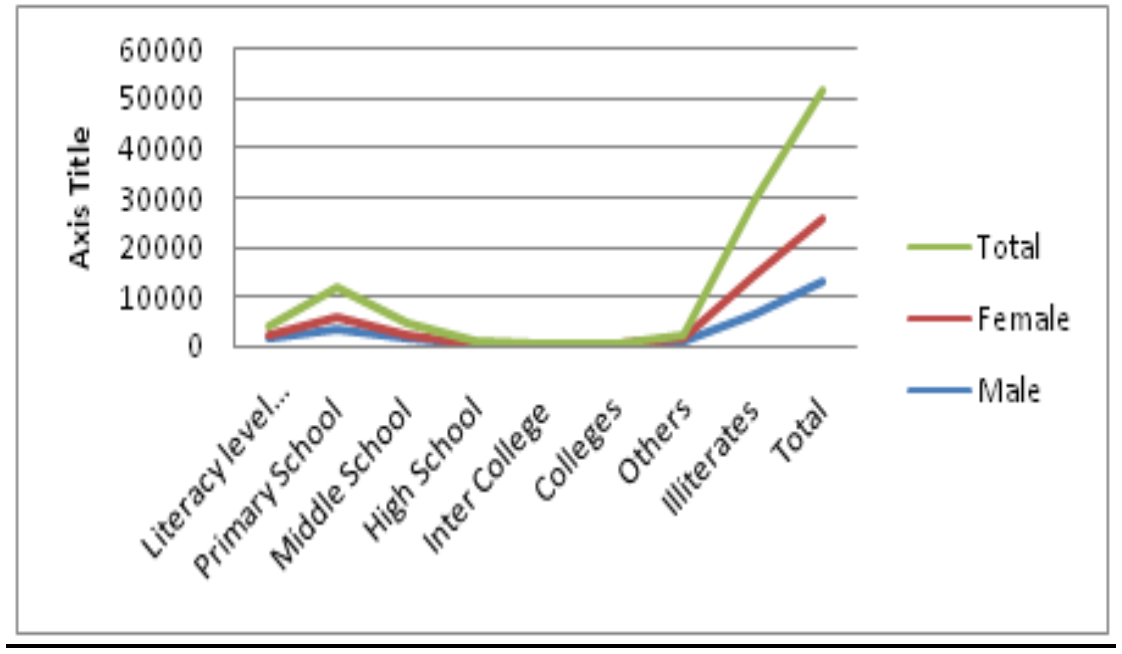


The main objective of these schemes is to educate the illiterate tribes and include them in the main stream of development, but these schemes are working but not at the required pace and these efforts are not successful completely. Therefore, even today these primary and high educations are not doing very good. The level of the current education is such low that due to this education, these tribe are not able to get the jobs as well as they are not able to include them into main development stream.

\section{SOlution AND CONCluSion}

We have studied the education and development of Baiga and the support level of Schemes lunched by Government which marked some improvement in their education and development, but there is a big gap and scope of improvements.

Except North-eastern, the education level of Baiga tribes is at unsatisfactory level. RASTRIYA SHIKSHA NEETI 1986, right of education act have spread awareness and the schemes are improving the education and development level of these tribes with some positive results, but need some more steps to be taken with high pace.

To improve Baiga educations and their life style, if required we need to amend education pattern according to them as well as their culture needs to include in their education system. The aim would not only to increase literacy level while they should be skilled to develop by themselves.

\section{REFERENCES}

[1] District statistics book (2011, Madla (M.P.)

[2] Chourasia Dr. Vijay "Prakarti Putra Baiga". M.P. Hindi Grantha Academy, Bhopal (2009)

[3] Gazetteer, District Madla.

[4] Raju S. Supara (2010) Development through Literacy, a study of Fishring community in Andhra Pradesh, Journal of Rural development N.I.R.D. (October-December Vol 29, No.-24)

\section{AUTHORS' BIOGRAPHY}

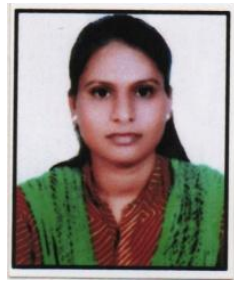

Ekta Mathaniyan is a research scholar in RDVV Jabapur (M.P.) and doing $\mathrm{PhD}$

Citation: Ekta Mathniyan. "Study of Education and Development of Baiga Tribe in District Mandla". International Journal of Research in Geography. vol 4, no. 1, 2018, pp. 14-16. doi:http://dx.doi.org/ 10.20431/2454-8685.0304003.

Copyright: (C) 2018 Authors. This is an open-access article distributed under the terms of the Creative Commons Attribution License, which permits unrestricted use, distribution, and reproduction in any medium, provided the original author and source are credited. 